Open Access

\title{
Erratum to: Short-term acreage forecasting and supply elasticities for staple food commodities in major producer countries
}

Mekbib G. Haile*, Jan Brockhaus and Matthias Kalku

* Correspondence: mekhaile@uni-bonn.de

Center for Development Research (ZEF), Bonn University, Bonn, Germany

\section{Erratum}

Following publication of the original article (Haile et al. 2016) it was brought to our attention that Fig. 1 was displaying incorrectly in the online version of the article due to additional shading. This has now been corrected on the BioMed Central website. Please find below a copy of the correct Fig. 1:

Received: 5 September 2016 Accepted: 5 September 2016 Published online: 26 September 2016

\section{Reference}

Haile MG et al. (2016) Short-term acreage forecasting and supply elasticities for staple food commodities in major producer countries. Agricultural and Food Economics 4:17
- Convenient online submission

- Rigorous peer review

- Immediate publication on acceptance

- Open access: articles freely available online

- High visibility within the field

- Retaining the copyright to your article

Submit your next manuscript at $\boldsymbol{s p r i n g e r o p e n . c o m ~}$ 


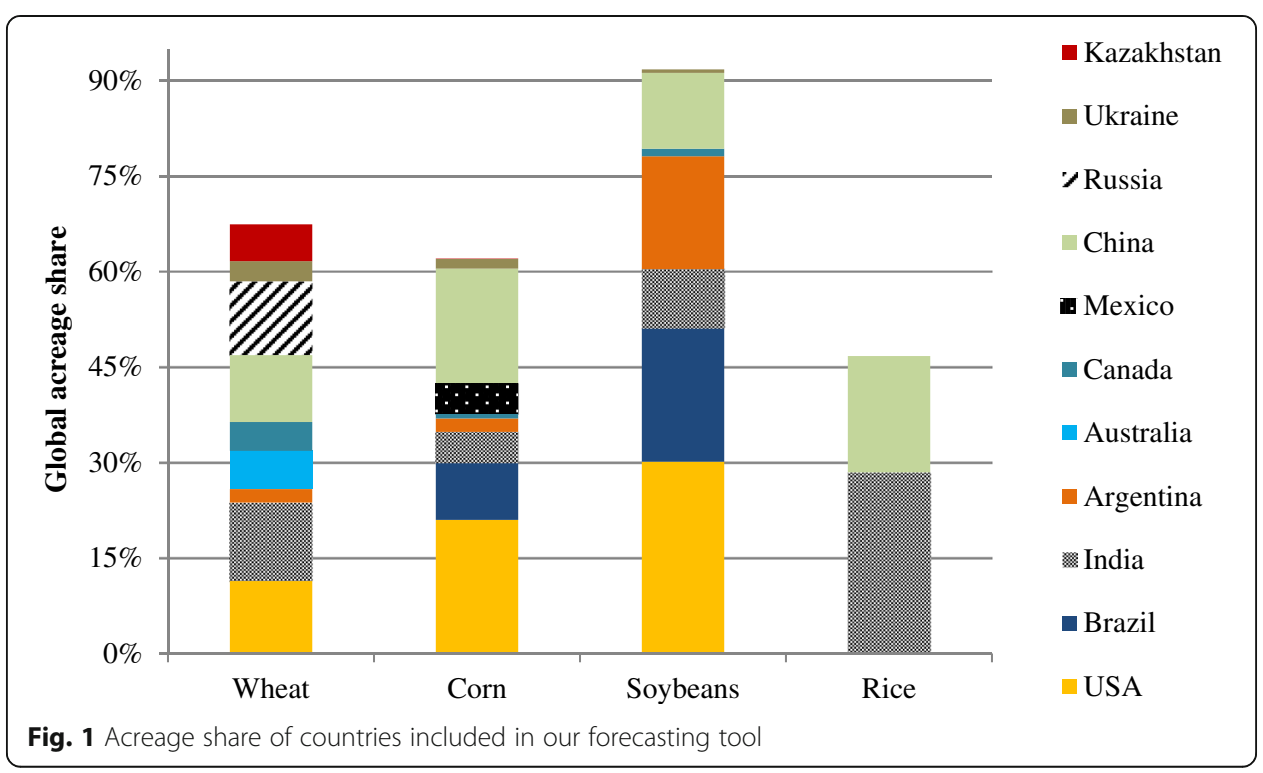

